\title{
The implementation strategy of Ecosystem Approach to Aquaculture (EAA) shrimp commodities in Pinrang District, South Sulawesi
}

\author{
Wisriati Lasima ${ }^{\mathrm{a}}$, Eddy Supriyono ${ }^{\mathrm{b}}$, Muhammad Zairin Junior ${ }^{\mathrm{b}}$, Sugeng Budiharsono ${ }^{\mathrm{c}}$, Kukuh Nirmal $^{\mathrm{b}}$, Sukenda $^{\mathrm{b}}$ \\ a Aquaculture Study Program, Graduate School, IPB University, Darmaga Bogor, 16680, Indonesia \\ ${ }^{\mathrm{b}}$ Department of Aquaculture, Faculty of Fisheries and Marine Sciences, IPB University, Darmaga Bogor, 16680, Indonesia \\ ${ }^{c}$ Postgraduate Program, University of Nusa Bangsa, Jl. KH Sholeh Iskandar KM 4, Tanah Sareal, Bogor 16166, Indonesia
}

\section{Article Info:}

Received: 02 - 06 - 2021

Accepted: $11-07-2021$

\section{Keywords:}

Ecosystem approach to aquaculture, shrimp, sustainable aquaculture

Corresponding Author:

Eddy Supriyono

Department of Aquaculture,

Faculty of Fisheries and Marine

Sciences, IPB University;

Tel. +628164800176

Email:

eddysupriyonoiipb@gmail.com

\begin{abstract}
This study aims to develop a strategy for the sustainability of shrimp aquaculture using an ecosystem approach or EAA in Pinrang Regency, South Sulawesi. A series of analyzes were carried out, namely the environmental carrying capacity analysis of aquaculture using pond environmental feasibility standards, analysis of critical factors for the sustainability of aquaculture using multidimensional scaling analysis, analysis of the sustainability status of aquaculture using pairwise comparison analysis and analysis of shrimp aquaculture management strategies based on EAA. Using hierarchy process analysis. The results showed that the following strategies were needed: a) accelerating spatial planning and implementing programs in accordance with the directions for spatial use and control; b) institutional strengthening of capital cultivators in order to complement and improve facilities and infrastructure in accordance with the SOP; and c) increasing the level of education and providing a social and economic security system for members of the shrimp farming community.
\end{abstract}

How to cite (CSE Style $8^{\text {th }}$ Edition):

Lasima W, Supriyono E, Junior MZ, Budiharsono S, Nirmal K, Sukenda. 2021. The implementation strategy of Ecosystem Approach to Aquaculture (EAA) shrimp commodities in Pinrang District, South Sulawesi. JPSL 11(3): $504-512$. http://dx.doi.org/10.29244/jpsl.11.3.504-512.

\section{INTRODUCTION}

South Sulawesi Province is the center of aquaculture production in Indonesia, spreading land over several districts. Pinrang Regency has the largest area for shrimp cultivation in South Sulawesi Province (KKP, 2016). Pinrang Regency has a shrimp pond area of 15026 ha or about $18 \%$ of the total area of shrimp ponds in South Sulawesi (KKP, 2016). Pinrang Regency is also one of the pilot minapolitan areas in Indonesia in developing tiger prawns, milkfish, and seaweed commodities. The minapolitan centers in Pinrang Regency are located in three villages in Suppa District, namely the villages of Lotang Solo, Wiringtasi, and Tasiwalie, known as the Lowita minapolitan area.

The area of shrimp ponds in Suppa District is the fifth of the six coastal sub-districts in Pinrang Regency, but the production of the pond is the largest. The area of ponds in Suppa sub-district is only about 1595.22 ha, and this area is smaller than other sub-districts such as Cempa, Duampanua, and Lembang. This phenomenon has occurred since the discovery of the Suppa shrimp population (Phronima sp.) and is used by local farmers as shrimp seed feed to replace the function of artemia in marginal ponds, which have been affected by outbreaks of White Spot Syndrome Virus (WSSV) and Vibrio harveyi bacteria during the period 1998-2007. The results of the use of micro-crustaceans from the genus Phronima have unexpectedly led to the successful 
harvest of shrimp in these marginal ponds of $150 \mathrm{~kg}$ shrimp/ha per growing season with a survival rate of around 50\% (Fattah et al., 2014). In this case, the use of Suppa shrimp is one of the ecosystem approaches that support the success of shrimp aquaculture in the region (Fattah et al., 2014).

In line with the management of aquaculture in Pinrang Regency, the Food and Agriculture Organization (FAO) since 2008 has also stated that sustainable aquaculture should indeed be carried out through the development of aquaculture based on the development of aquaculture ecosystem approach to aquaculture (EAA). The application of EAA meets three principles: a) Aquaculture development and management must be carried out in the context of ecosystem functions and services; b) Aquaculture should promote human wellbeing and equity for all relevant stakeholders; c) Aquaculture should be developed in the context of (and integrated with) other relevant sectors, including policies and objectives (FAO, 2010). In relation to the three EAA principles, experts also agree on three scales for the application of EAA: a) aquaculture unit scale; $b$ ) the scale of relevant water bodies and watersheds; and c) global scale refers to the global industry for some commodity products (eg: salmon and shrimp) and global issues such as trade, certification, technological progress, research and education of global relevance, etc. (FAO, 2008).

This research was conducted to obtain a strategy for implementing EAA based on environmental carrying capacity and critical factors that affect the sustainability of shrimp aquaculture in Pinrang Regency. In addition, this study will increase knowledge about the application of EAA in shrimp aquaculture in other production centers in Indonesia, considering that a similar study has only been conducted in Sinjai, South Sulawesi, for milkfish (Nachos nachos) aquaculture (Kurniati et al., 2018).

\section{METHOD}

\section{Study Area and Period}

The research was carried out for six months, from May 2019 to August 2020. The research site is the aquaculture area of Wiringtasi Village, Tasiwalie, and Lotangsalo, Suppa Subdistrict, Pinrang Regency, South Sulawesi Province. The site selection was carried out purposively, namely based on the following criteria: a) The location for the development of shrimp culture with the application of Phronima Suppa feed, and b) The number of fish cultivating households is quite significant compared to the total number of households in the area.

\section{Data Collection}

The data used in this research are primary and secondary data. In this study, the data sources are the parties related to the management of aquaculture from shrimp aquaculture business actors and aquaculture stakeholders. Data on the environmental carrying capacity of aquaculture in the form of water quality is obtained through in situ and ex situ measurements and analysis, as well as literature searches from various government agencies and research. Evaluation data on critical factors was obtained through literature study with a guide on tracing matters related to the assessment of indicators for each dimension in various government agencies and research institutions and interviews with informants using a list of variables. The data for evaluating the sustainability of aquaculture and the design of aquaculture management policies and strategies for implementing EAA in aquaculture in Pinrang Regency were obtained from data from MDS analysis and expert assessments.

\section{Data Analysis}

Analysis of the environmental carrying capacity of aquaculture was analyzed using environmental feasibility standards for ponds (Utojo et al., 2009). Analysis of critical factors from each dimension, namely Ecological, Technological, Economic, Social, and Institutional determined based on literature studies (Bailey, 2008; Costa-Pierce, 2008; Knowler, 2008), which affect the sustainability of aquaculture based on EAA was 
carried out using multidimensional scaling analysis techniques. (Budiharsono, 2018) and the results are used to analyze the sustainability status of aquaculture using pairwise comparison analysis (Budiharsono, 2018). The critical factors obtained are then used to formulate policies for shrimp aquaculture management in Pinrang Regency and the implementation strategy based on the EAA. The arrangement was obtained using the analytic hierarchy process technique (Saaty, 2008). The data collected along with the data collection and analysis methods used are presented in Table 1.

Table 1 Research stages of the strategy for implementing the Ecosystem Approach to Aquaculture (EAA) shrimp commodity in Pinrang Regency, South Sulawesi

\begin{tabular}{|c|c|c|c|c|c|}
\hline No. & Research Stages & Types of Data & $\begin{array}{c}\text { Data } \\
\text { Collection } \\
\text { Method }\end{array}$ & $\begin{array}{c}\text { Data Analysis } \\
\text { Method }\end{array}$ & Expected Result \\
\hline 1 & $\begin{array}{l}\text { Evaluating the } \\
\text { environmental carrying } \\
\text { capacity of shrimp } \\
\text { aquaculture in Pinrang } \\
\text { Regency, South Sulawesi }\end{array}$ & $\begin{array}{l}\text { - Physical data of } \\
\text { shrimp farming land } \\
\text { - Physical and } \\
\text { biological data of } \\
\text { shrimp aquaculture }\end{array}$ & $\begin{array}{c}\text { Literature } \\
\text { study, } \\
\text { survey }\end{array}$ & $\begin{array}{l}\text { Environmental } \\
\text { suitability and } \\
\text { carrying capacity } \\
\text { analysis (Utojo } \\
\text { et al., 2019) }\end{array}$ & $\begin{array}{l}\text { Environmental } \\
\text { carrying capacity of } \\
\text { aquaculture }\end{array}$ \\
\hline 2 & $\begin{array}{l}\text { Evaluating critical factors } \\
\text { that affect the level of } \\
\text { sustainability of shrimp } \\
\text { aquaculture in Pinrang } \\
\text { Regency, based on the } \\
\text { EAA approach }\end{array}$ & $\begin{array}{l}\text { Ecological, } \\
\text { technological, } \\
\text { economic, social, } \\
\text { and institutional } \\
\text { data }\end{array}$ & Survey & $\begin{array}{c}\text { MDS Analysis } \\
\text { (RapADPEh) } \\
\text { (Budiharsono, } \\
\text { 2018) }\end{array}$ & $\begin{array}{l}\text { The carrying } \\
\text { capacity of the } \\
\text { ecological, } \\
\text { technological, } \\
\text { economic, social, } \\
\text { institutional } \\
\text { dimensions of } \\
\text { aquaculture }\end{array}$ \\
\hline 3 & $\begin{array}{l}\text { Knowing the } \\
\text { sustainability status of } \\
\text { shrimp aquaculture in } \\
\text { Pinrang Regency,bBased } \\
\text { on the EAA approach }\end{array}$ & $\begin{array}{l}\text { Data from the } \\
\text { analysis of } \\
\text { ecological, } \\
\text { technological, } \\
\text { economic, social, } \\
\text { and institutional } \\
\text { carrying capacity }\end{array}$ & $\begin{array}{l}\text { Literature } \\
\text { study, } \\
\text { survey }\end{array}$ & $\begin{array}{c}\text { Pairwise } \\
\text { Comparation } \\
\text { Matrix } \\
\text { (Budiharsono, } \\
\text { 2018) }\end{array}$ & $\begin{array}{l}\text { Status of } \\
\text { aquaculture } \\
\text { sustainability based } \\
\text { on the ecosystem } \\
\text { approach }\end{array}$ \\
\hline 4 & $\begin{array}{l}\text { Designing a shrimp } \\
\text { culture fishery } \\
\text { management policy based } \\
\text { on the ecosystem } \\
\text { approach needed to } \\
\text { realize a sustainable } \\
\text { shrimp aquaculture } \\
\text { fishery in Pinrang } \\
\text { Regency, South Sulawesi }\end{array}$ & $\begin{array}{l}\text { Data Leverage } \\
\text { Attribute }\end{array}$ & $\begin{array}{l}\text { Literature } \\
\text { study, } \\
\text { survey }\end{array}$ & $\begin{array}{c}\text { AHP } \\
\text { (Saaty, 2008) }\end{array}$ & $\begin{array}{l}\text { Policy design for } \\
\text { shrimp aquaculture } \\
\text { development based } \\
\text { on an ecosystem } \\
\text { approach }\end{array}$ \\
\hline
\end{tabular}

\section{RESULT AND DISCUSSION}

\section{Evaluation of Environmental Carrying Capacity of Shrimp Cultivation Fisheries in Pinrang}

The results of the analysis using secondary data on the environmental quality of ponds (Syam et al., 2018) (Table 2) and primary data on pond water quality (Table 3 ) indicate that the feasibility level of shrimp ponds 
in the research location is included in the "Very Appropriate" category (S1) with a range of feasibility values between $>8.4$ to 10 . The results of the analysis of water quality in the typical rainy and dry seasons are relatively the same. However, water quality based on $\mathrm{pH}$ and $\mathrm{PO}_{4}$ parameters show a decrease during the dry season.

Table 2 Environmental carrying capacity based on water quality for shrimp aquaculture fisheries in Pinrang Regency in the rainy and dry season in 2018

\begin{tabular}{|c|c|c|c|c|}
\hline Parameter & Weight & Measurement results & Score & Value \\
\hline Rainy season & & & & 9.25 \\
\hline Land Quality & & & & 3.40 \\
\hline Slope & 0.20 & 0.03 & 4 & 0.80 \\
\hline Distance from the beach & 0.20 & 1000 & 2 & 0.40 \\
\hline Distance from river & 0.20 & $300-1600$ & 3 & 0.60 \\
\hline Type of soil & 0.05 & Alluvial Pantai & 4 & 0.20 \\
\hline pond height & 0.20 & 1.1-1.2 & 4 & 0.80 \\
\hline Geology & 0.05 & Sedimen lepas & 4 & 0.20 \\
\hline Drainage & 0.10 & Tergenang & 4 & 0.40 \\
\hline Water quality & & & & 5.85 \\
\hline Salinity (ppt) & 0.30 & $7-22$ & 2 & 0.60 \\
\hline Temperature $\left({ }^{\circ} \mathrm{C}\right)$ & 0.30 & $27-31$ & 4 & 1.20 \\
\hline Dissolved oxygen $(\mathrm{mg} / \mathrm{l})$ & 0.30 & $5.4-8.9$ & 4 & 1.20 \\
\hline $\mathrm{pH}$ & 0.30 & $6.14-9.73$ & 4 & 1.20 \\
\hline $\mathrm{PO}_{4}(\mathrm{mg} / \mathrm{l})$ & 0.10 & $0.05-0.10$ & 3 & 1.20 \\
\hline $\mathrm{NH}_{3}(\mathrm{mg} / \mathrm{l})$ & 0.10 & $0.05-0.10$ & 3 & 0.30 \\
\hline $\mathrm{NO}_{2}(\mathrm{mg} / \mathrm{l})$ & 0.10 & $0.05-0.10$ & 3 & 0.15 \\
\hline Dry Season & & & & 8.80 \\
\hline Land Quality & & & & 3.40 \\
\hline Water quality & & & & 5.40 \\
\hline Salinity (ppt) & 0.30 & $7-22$ & 2 & 0.60 \\
\hline Temperature $\left({ }^{\circ} \mathrm{C}\right)$ & 0.30 & $27-31$ & 2 & 0.60 \\
\hline Dissolved oxygen $(\mathrm{mg} / \mathrm{l})$ & 0.30 & $5.4-8.9$ & 4 & 1.20 \\
\hline $\mathrm{pH}$ & 0.30 & $6.14-9.73$ & 3 & 0.90 \\
\hline $\mathrm{PO}_{4}(\mathrm{ppm})$ & 0.10 & $0.05-0.10$ & 3 & 1.20 \\
\hline $\mathrm{NH}_{3}(\mathrm{ppm})$ & 0.10 & $0.05-0.10$ & 3 & 0.30 \\
\hline $\mathrm{NO}_{2}(\mathrm{ppm})$ & 0.05 & $0.05-0.10$ & 3 & 0.15 \\
\hline
\end{tabular}

Source: Syam et al., (2018); Notes: The weights and scores are based on the standard of environmental feasibility of ponds which are sourced from Utojo et al. (2009)

This water quality condition indicates the magnitude of the influence of water circulation in the pond. During the dry season, the water circulation that occurs is not sufficient to stabilize the $\mathrm{pH}$ dynamics that occur. On the other hand, water input from upstream areas is predicted to carry pollutants and sedimentation from human activities, which cannot be neutralized through existing water circulation. One of the contributors to phosphate is the community's domestic waste. According to WHO \& European Commission (2002), phosphorus enrichment in waters mainly comes from household and industrial wastes, including phosphorusbased detergents. However, aquatic biota needs phosphate levels for life; if in excessive concentrations, it will have a dangerous impact. High amounts of phosphate will result in very large algae growth and less sunlight entering the waters. When algae die, bacteria will break them down using dissolved oxygen in the water (Green, 2018). 
Table 3 Water quality of shrimp farming ponds in Pinrang Regency, 2020

\begin{tabular}{|c|c|c|c|c|c|c|c|c|c|c|c|c|c|c|}
\hline \multirow{2}{*}{ Parameter } & \multirow{2}{*}{ Unit } & \multicolumn{12}{|c|}{ Location } & \multirow{2}{*}{ Estimation } \\
\hline & & A1 & A2 & A3 & B1 & B2 & B3 & $\mathrm{C} 1$ & $\mathrm{C} 2$ & C3 & D1 & D2 & D3 & \\
\hline \multicolumn{15}{|l|}{ Rainy season } \\
\hline Temperature & ${ }^{\circ} \mathrm{C}$ & 24.9 & 23.9 & 25.3 & 25.1 & 32.4 & 24.4 & 27.0 & 26.6 & 26.4 & 27.8 & 27.0 & 29.1 & $24.4-29.1$ \\
\hline Salinity & $\%$ & 13 & 17 & 15 & 15 & 7 & 9 & 14 & 12 & 22 & 21 & 11 & 8 & $7-22$ \\
\hline $\mathrm{pH}^{*}$ & & 10.3 & 9.5 & 9.9 & 7.9 & 8.8 & 8.5 & 7.8 & 7.9 & 8.5 & 8.3 & 8.5 & 7.5 & $7.5-10.3$ \\
\hline $\mathrm{PO}_{4} *$ & $\mathrm{ppm}$ & 0.05 & 0.01 & 0.05 & 0.05 & 0.05 & 0.05 & 0.05 & 0.05 & 0.08 & - & 0.06 & 0.08 & $0.01-0.08$ \\
\hline $\mathrm{NH}_{3}$ & ppm & - & 0.03 & 0.03 & - & 0.05 & - & & 0.05 & 0.05 & - & 0.05 & 0.05 & $\leq 0.05$ \\
\hline $\mathrm{NO}_{2}$ & ppm & - & - & - & - & - & - & 0.05 & - & - & - & - & - & $\leq 0.05$ \\
\hline \multicolumn{15}{|l|}{ Dry Season } \\
\hline Temperature & ${ }^{\circ} \mathrm{C}$ & 29.0 & 29.0 & 29.5 & 28.0 & 29.0 & 28.0 & 29.0 & 28.5 & 29.0 & 29.0 & 29.0 & 30.5 & $28.0-30.5$ \\
\hline Salinity & $\%$ & 9 & 16 & 8 & 14 & 35 & 18 & 28 & 30 & 36 & - & 38 & 20 & 8-30 \\
\hline $\mathrm{pH}^{*}$ & & 7 & 7 & 6.1 & 6.9 & 7.1 & 7.5 & 7.5 & 13.7 & 9.7 & 7.11 & 9.7 & 7.4 & $6.1-13.7$ \\
\hline $\mathrm{PO}_{4} *$ & ppm & 0.10 & 0.10 & 0.08 & 0.05 & 0.05 & 0.05 & 0.08 & 0.08 & 0.10 & 0.08 & 0.08 & 0.08 & $0.05-0.10$ \\
\hline $\mathrm{NH}_{3}$ & ppm & 0.05 & 0.05 & 0.05 & 0.05 & 0.05 & 0.05 & 0.05 & 0.05 & 0.05 & 0.05 & 0.05 & 0.05 & 0.5 \\
\hline $\mathrm{NO}_{2}$ & ppm & 0.05 & 0.05 & 0.05 & 0.05 & 0.05 & 0.05 & 0.05 & 0.05 & 0.05 & 0.05 & 0.05 & 0.05 & 0.5 \\
\hline
\end{tabular}

Source: Primary data, processed (2020); *significantly different

The importance of water circulation in well-functioning ponds was seen during the extreme dry season in 2019. At that time, the lack of water supply from the Jampue River led to decreased water quality due to increased salinity, $\mathrm{pH}$, and nutrient concentrations. The impact is the inhibition of the growth rate of shrimp in the pond.

\section{Evaluation of Critical Factors Affecting the Sustainability of Shrimp Cultivation Fisheries}

Based on the EAA approach used, five dimensions determine the sustainability of shrimp pond fisheries in Pinrang Regency: ecological, technological, economic, social, and institutional dimensions. Each dimension has variables/attributes and indicators. All values of each indicator were processed using MDS analysis and found that the S-Stress value ranged from 0.14 to 0.15 and the RSQ was in the range of 0.94, which means the model can be used (Alder et al., 2000; Budiharsono, 2018). Based on the results of the MDS analysis, the (ordinal) index values for each of these dimensions are presented schematically in Figure 1.

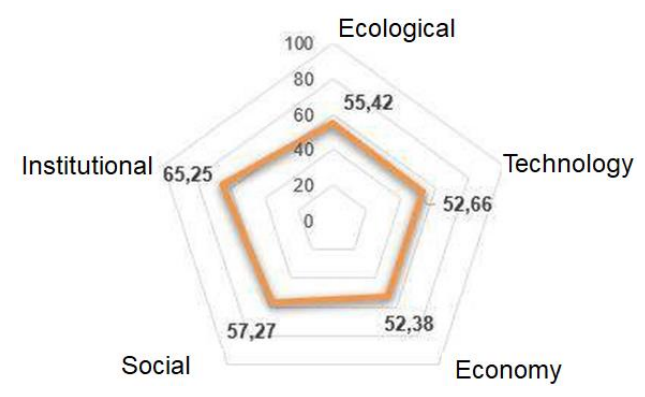

Figure 1 Dimensional index value of aquaculture management based on EAA in Pinrang Regency

(Source: Primary data, processed)

The index value of the five dimensions is strongly influenced by the leverage factor, which is a factor that can leverage the performance of each dimension to support shrimp aquaculture in Pinrang Regency in a sustainable manner, as presented in Figure 2. 
Leverage Factor Ecological Dimension

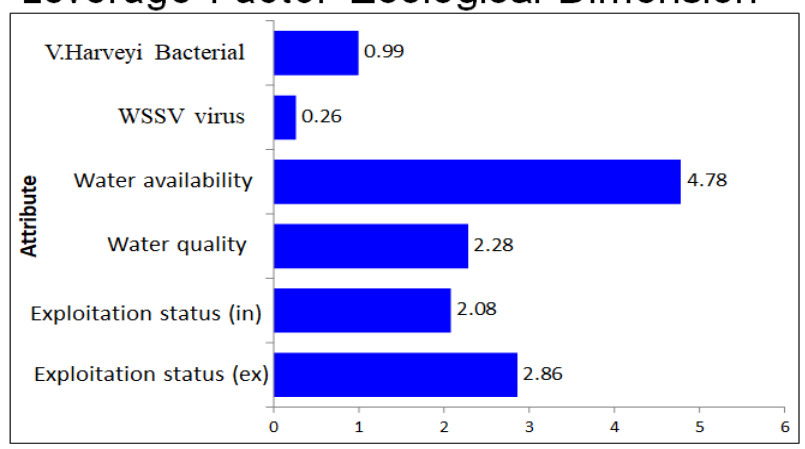

Leverage Factor Economic Dimension

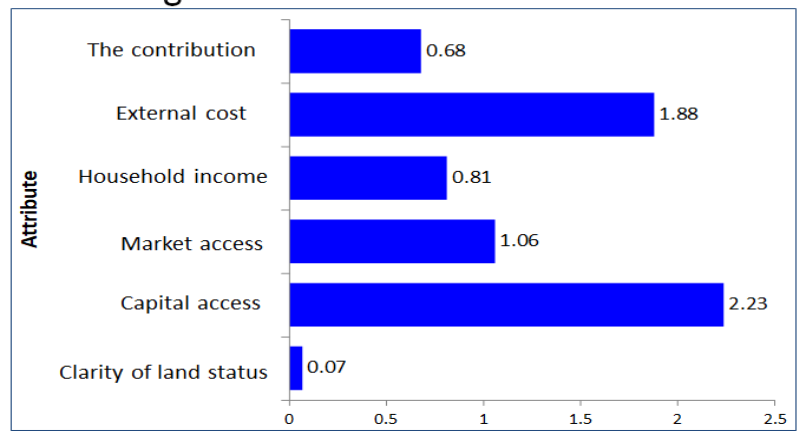

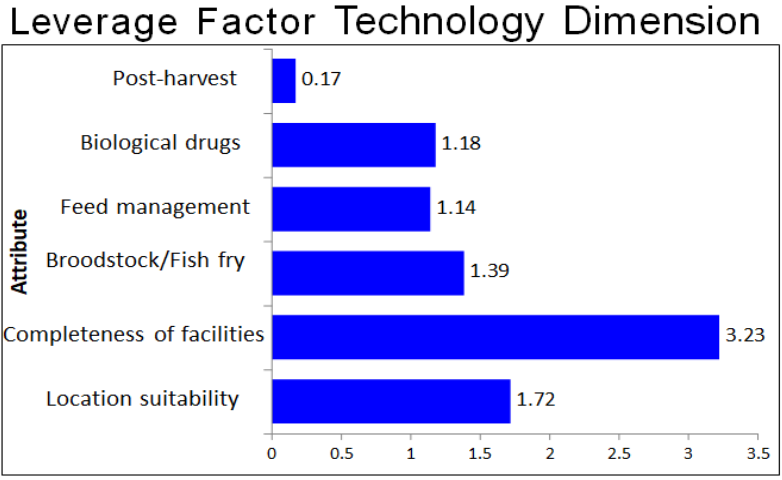

Leverage Factor Social Dimension

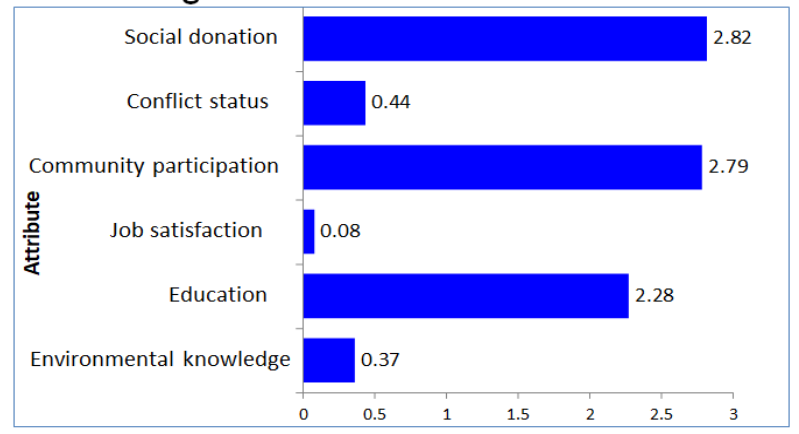

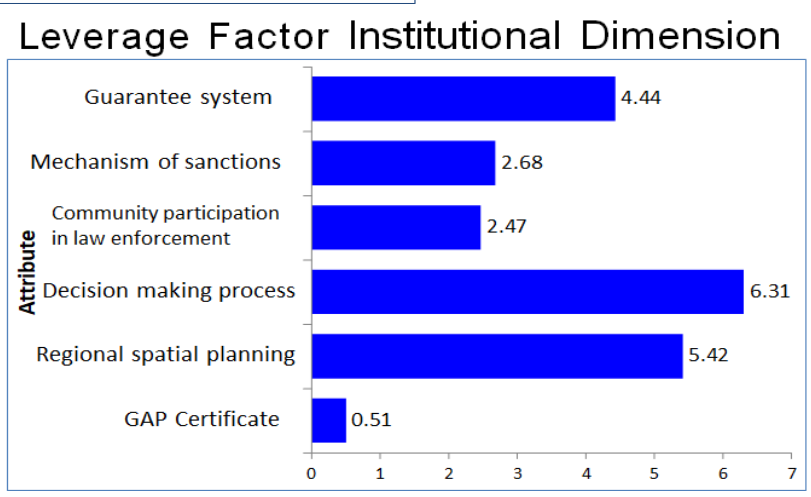

Figure 2 Critical factors (leverage factor) in each dimension of aquaculture management based on the EAA approach in Pinrang Regency

It can be seen in Figure 2 that the critical factor for the Ecological dimension is the availability of water, the critical factor for the Technological dimension is the completeness of the infrastructure, the critical factor for the Economic dimension is access to business capital and external costs, the critical factor for the Social dimension is the involvement of local communities, social contributions and education, and the critical institutional dimensions are the decision mechanism, the determination of the RTRW and the socio-economic security system. These critical factors become critical factors for the success of determining the Policy for Management of Shrimp Aquaculture Based on the EAA Approach in Pinrang Regency.

\section{Evaluation of the Sustainability of Shrimp Cultivation}

The result of the total of all multiplication of weighted weights with dimensional index values produces a composite index of Shrimp Cultivation Fisheries Management based on the EAA Approach (IPB-EAA) in Pinrang Regency of 59.7932 or shrimp pond fishery areas in Pinrang Regency which are analyzed are in a "Developing" condition. This condition requires comprehensive policy and program interventions to develop sustainable fisheries based on the EAA approach. Table 3 presents the process of determining the Shrimp Cultivation Fisheries Management index based on the EAA Approach (IPB-EAA) in Pinrang Regency. 
Table 3 Determination of the shrimp aquaculture management index based on the EAA Approach (IPB-

EAA) in Pinrang Regency, 2020

\begin{tabular}{cccc}
\hline Dimention & Weight & Dimension Index & Composite Index \\
\hline Ecology & 0.2017 & 55.4226 & 11.1799 \\
Technology & 0.0476 & 52.6631 & 2.5070 \\
Economy & 0.0912 & 53.3838 & 4.8671 \\
Social & 0.2248 & 57.2707 & 12.8743 \\
Institutional & 0.4347 & 65.2509 & 28.3649 \\
\hline Amount & 1.0000 & & 59.7932 \\
\hline
\end{tabular}

\section{Policy Design of Shrimp Aquaculture Management Based on the EAA Approach in Pinrang}

The critical factors obtained from the leverage analysis are then used to formulate the design of the Shrimp Aquaculture Fisheries Management Policy Based on the EAA Approach in Pinrang Regency. The analysis results presented in Figure 3 show that the management policy of shrimp aquaculture based on the EAA approach in Pinrang Regency is prioritized on improving the governance of natural resources and the environment as the basis for development. This is indicated by the Institutional Dimension as a priority, followed by the Ecological Dimension. Inclusive development policies, namely building active participation of all interested parties, are the next priority. Through the empowerment of social capital, it is hoped that it can help provide solutions to problems related to the Economic Dimension and the Technological Dimension.

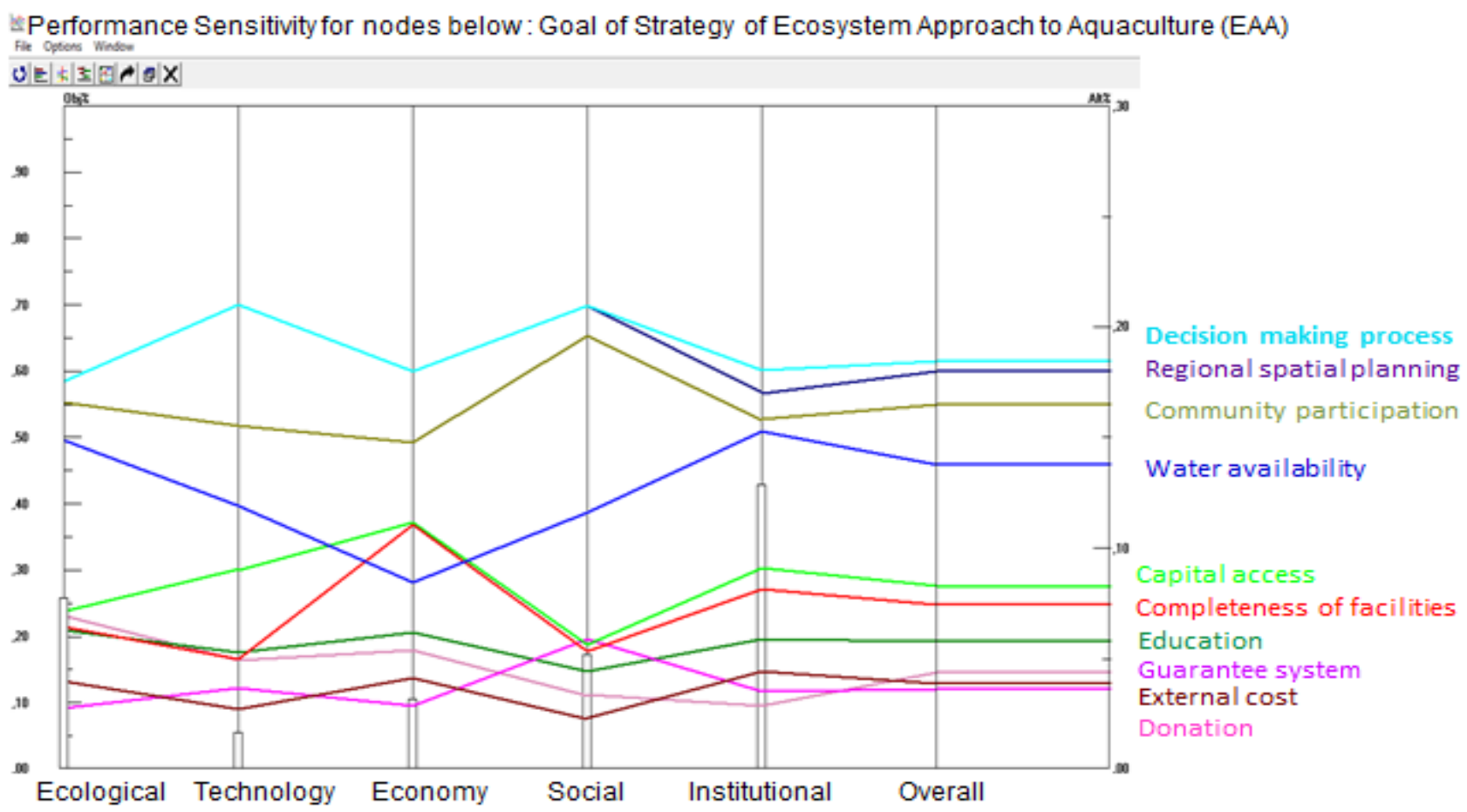

Figure 1 The results of the AHP analysis for the design of shrimp aquaculture fisheries management policies based on the EAA approach in Pinrang Regency

The critical factors of dimension variables/attributes serve as a guide in formulating strategies that support the policy direction as has been obtained at the Dimension level. The first strategy is to prioritize the acceleration of spatial planning and implement programs that follow the direction of space utilization and control, starting from the upstream to downstream areas. An indicator of the success of implementing this strategy is the availability of water that is in accordance with the need for the sustainable development of shrimp aquaculture. 
A stable water supply will help stabilize the environmental feasibility of the pond and maintain optimal land productivity potential. To accelerate the increase in economies of scale and business sustainability, a Second Strategy is needed, namely institutional strengthening that can help shrimp cultivators access capital, especially in order to complete and improve the facilities and infrastructure needed in accordance with the SOPs that have been set.

The next strategy, namely the Third Strategy, is to increase the level of education and provide a social and economic security system for members of the shrimp farming community. A high level of education is expected to provide insight and knowledge needed in finding solutions to problems faced, both in the short and medium and in the long term. Social and economic security offers benefits in improving the trading system for aquaculture products. Through this social and economic security system, shrimp farming communities can escape from the entanglements of middlemen, especially when they face crop failures or poor harvests, as capital to cover their living costs and sustain their business.

\section{CONCLUSION}

The implementation of decision-making mechanisms, especially those related to spatial planning policies, has not involved the community, so it impacts water availability. The status of cultivation in Suppa Subdistrict, Pinrang Regency, South Sulawesi is in the "Sufficiently Sustainable" category. However, policies are needed to make it sustainable, namely with the strategy: a) Spatial planning, b) Strengthening people's economic institutions, and c) Increasing the level of education and providing a guaranteed system social welfare and access to capital for members of the shrimp farming community.

\section{REFERENCES}

[FAO] Food and Agriculture Organization. 2008. Building an ecosystem approach to aquaculture. FAO Fisheris and Aquaculture Proceeding 14. Rome (IT): FAO Fisheries and Aquaculture Department. p 221.

[FAO] Food and Agriculture Organization. 2010. Ecosystem Approach to Aquaculture. Rome (IT): FAO. p 53.

[KKP] Kementerian Kelautan dan Perikanan. 2016. Peta Sentra Produksi Perikanan Budidaya. Jakarta (ID): Kementerian Kelautan dan Perikanan.

[WHO \& European Commission] World Health Organization and European Commission. 2002. Eutrophication and Health. Luxembourg: Office for Official Publication of the European Communities. p 28.

Alder J, Pitcher TJ, Preikshot D, Kaschner K, Feriss B. 2000. How good is good? a rapid appraisal technique for evaluation of the sustainable status of fisheries of the North Atlantic. In: Pauly, Pitcher, Editor. Methods for evaluation the impacts of fisheries on the North Atlantic Ecosystem. Fisheries Center Research Reports. 8(2): 120-131.

Bailey C. 2008. Human dimensions of an ecosystem approach to aquaculture. In: Soto D, Aguilar-Manjarrez $\mathrm{J}$, Hishamunda N, editor. Building an ecosystem approach to aquaculture. FAO/Universitat de les Illes Balears Expert Workshop; FAO Fisheries and Aquaculture Proceeding; 2007 May 7-11; Palma de Mallorca, Spain. Rome (RO): FAO. p 37-46.

Budiharsono S. 2018. Membangun Keajaiban Wilayah Perdesaan. Bogor (ID): IPB Press.

Costa-Pierce B. 2008. An Ecosystem Approach to marine aquaculture: a global review. In: Soto D, AguilarManjarrez J, Hishamunda N, editor. Building an ecosystem approach to aquaculture. FAO/Universitat de les Illes Balears Expert Workshop; FAO Fisheries and Aquaculture Proceedings; 2007 May 7-11; Palma de Mallorca, Spain. Rome (RO): FAO. p 81-115. 
Fattah MH, Saenong M, Asbar, Busaeri R St. 2014. Production of endemic microcrustacean phronima suppa (Phronima sp) to subtitute artemia salina in tiger prawn cultivation. J Aquac Res Development. 5(5): 15. doi: 10.4172/2155-9546.1000257.

Green J. 2018. How do Phosphates Affect Water Quality? [Internet]. [Downloaded 2021 Apr 19]. Available at: https://sciencing.com/phosphates-affect-water-quality4565075.html.

Knowler D. 2008. Economic implications of an ecosystems approach to aquaculture (EAA). In: Soto D, Aguilar-Manjarrez J, Hishamunda N, editor. Building an ecosystem approach to aquaculture. FAO/Universitat de les Illes Balears Expert Workshop; FAO Fisheries and Aquaculture Proceeding; 2007 May 7-11; Palma de Mallorca, Spain. Rome (RO): FAO. p 47-65.

Kurniati A, Tantu AG, Indrawati E. 2018. Penilaian status pengelolaan perikanan budidaya ikan bandeng (Chanos chanos) dengan pendekatan ekosistem di Kabupaten Sinjai. J of Aquac.Environment. 1(1): 117.

Saaty TL. 2008. Decision making with the analytic hierarchy process. J Services Sciences. 1(1): 83-98.

Syam SM, Fattah MH, Asbar. 2018. Analisis kelayakan pencadangan kawasan shrimp eco-farming di Kabupaten Pinrang. Journal of Indonesian Tropical Fisheries. 1(1): 59-68.

Utojo, Mustafa A, Rachmansyah, Hasnawi. 2009. Penentuan lokasi pengembangan budi daya tambak berkelanjutan dengan aplikasi sistem informasi geografis di Kabupaten Lampung Selatan. J Ris Akuakultur. 4(3): 407-423. 